Following the publication on May 12 of the report of the Court of Inquiry into last year's explosion at the Nypro chemical plant, the inhabitants of the villages around Flixborough are not alone in their misgivings over the report's assertion that "the siting of the works ..." (in a sparsely populated area) ". . . was fortunate". Residents of the densely populated London boroughs of Ilford, Newham and Barking, who also live in the shadow of a chemical factory which formerly manufactured, and still stores, cyclohexane, are awaiting the outcome of an inquiry into a recent accident at the factory.

The accident, which resulted in the death of a 52-year-old worker, occurred on April 5, 1975, when the plant used in the manufacture of sorbitol exploded in the Ilford factory of Laporte Industries, a British-owned chemical company. The inquiry into the Laporte incident is the first to be ordered by the newly formed Health and Safety Commission whose involvement lends a wider interest to a continuing dispute over the siting of chemical plants that had already developed between the factory management and anxious local residents.

Laporte Industries moved to Ilford in 1961 after taking over the factory from a small pharmaceuticals company and since the move phthalic anhydride, cyclohexane, and sorbitol have, at various times, been manufactyred there. Ever since the arrival of the company local people have been concerned about the standard of safety regulations enforced within the factory, claiming that the company has, until recently, acted less than openly with them. In spite of official assurances that everything possible is done to maintain satisfactory safety standards several incidents had occurred before the latest accident.

In 1969 part of the plant used to solution following an explosion in a manufacture phthalic anhydride ex- hydrogen plant used in the manufacture ploded. After the Flixborough disaster of sorbitol. The Factory Inspectorate last June it became known that earlier are said to have visited plant associated the same year a small fire had broken with the hydrogen plant only a few out in the cyclohexane plant in Ilford. weeks before the accident. FurtherThis was the first time that the residents more, the RESC claim to have underbecame aware of the dangers posed by

\section{Chemical plants on the doorstep}

$$
\text { by Allan Piper }
$$

the manufacture of cyclohexane. Although the process was only being operated on a tenth of the scale of that at Flixborough, the Ilford factory is situated in a densely populated area and backs immediately on to a primary school of 650 pupils. Though cyclohexane and phthalic anhydride are no longer manufactured there, both chemicals are still stored there in large quantities.

Local concern led to the formation last year of a tenants' association, the Roding Environmental Safety Campaign (RESC), which is pressing Laporte to provide details of all hazardous processes operated at the factory and wants to see acceptable safety standards implemented at all plants.

But open days held at the factory last year were not reassuring. Neither is the RESC happy about the circumstances under which the cyclohexane plant was permanently shut down last October after a visit by the Factory Inspectorate. In their annual shareholders report, however, Laporte maintain that the closure was purely in deference to the understandable apprehension of local residents and was unconnected with the visit.

The worker who died in April was severely splashed with caustic potash stood from the company that sorbitol was a "safe" chemical and were not informed that part of the manufacturing process involved some risk.

The RESC has already pressed Parliament for a public enquiry into the running of the factory and a consideration of the siting of dangerous processes in the area. On April 11 Dennis Howell, the Minister of State for the Department of the Environment, expressed a willingness to help but on the question of siting he pointed out that "the Laporte factory was there before the houses and the school were erected, and not the other way round".

The RESC have at least obtained some backing from Redbridge Council who said earlier this month that they would continue to press Michael Foot, the Minister responsible, for a public enquiry into the safety of the works. In the same statement they also referred specifically to enquiries being conducted into the recent accident and said that the Factory Inspectorate had agreed to meet both the Council and the RESC to discuss the inquiry report following its publication.

Whether or not such discussions ever take place will depend entirely upon the Health and Safety Commission: the commission has stated that it would be left to them to "decide whether or not a report is to be published". Though officially they may not allow such a decision to be swayed by matters outside the incident under investigation it is unlikely that they will miss the opportunity to set a healthy precedent. as a forum for scientific exchange independent of government and party policy.

The current atmosphere of détente lays considerable stress on scientific contact and exchange. The Soviet authorities, however, says Professor Voronel, wish to monopolise these contacts. Whether the recent flood of scientific and technological cooperation agreements which the Soviet Union has been signing will result in a genuine exchange of scientific opinions and information, not to the benefit of any one country, but to that of science as a whole rests, says Voronel, not with the politicians, but with the scientists. Now is the crucial time, he stresses, for western scientists to establish "new conditions and forms of contact" with their Soviet colleagues.

\section{Manpower planning and higher education}

by Eleanor Lawrence

MANPOWER planning should have a greater part to play in decisions about the future expansion of British universities and polytechnics, according to Lord Crowther-Hunt, Minister of State overseeing higher education.

Speaking at a conference in London last week, he said that "at a time of economic and financial difficulty we need to be more than ever certain that the money we spend is well spent". $\mathrm{He}$ emphasised that "it simply will not do to allow universities and polytechnics to produce whatever people they fancy or to relate the number and kind of places they provide to the applicants that come forward". This was a passive approach which ignored policy variables which were in fact at the disposal of the government.

Undeterred by the admitted lack of success of previous efforts to forecast manpower demand, Lord CrowtherHunt said that he wished to pursue a "positive approach to higher educated manpower, both to look again at what might be the needs of the economic system and to ask questions not simply about numbers of qualified people lut the nature of the qualifications".

The Government could influence the situation in several ways, said Lord Crowther-Hunt. "At the one extreme, student grants and the counselling services of schools can surely affect the demand for places in higher education. At the other a considerable frac- 